\title{
Peran Guru Pendidikan Kewarganegaraan dalam Mencegah Kenakalan Remaja di Sekolah
}

\author{
Dasu Oka Wulandari \& Hodriani* \\ Jurusan Pendidikan Pancasila dan Kewarganegaraan, Fakultas Ilmu Sosial \\ Universitas Negeri Medan, Indonesia.
}

Diterima: Februari 2019; Disetujui: Maret 2019; Dipublish: April 2019

*E-mail: $\underline{\text { hodriani@unimed.ac.id }}$

\begin{abstract}
Abstrak
Penelitian ini bertujuan untuk mengetahui bagaimana peran guru Pendidikan Kewarganegaraan (PKn) dalam mencegah kenakalan remaja, serta hambatan yang dialami oleh guru. Adapun metode penelitian yang digunakan penulis adalah deskriptif kuantitatif. Jumlah populasi dalam penulisan ini adalah seluruh siswa SMK PAB 164 orang siswa yang berasal dari kelas X, XI, XII. Maka yang menjadi sampel dalam penelitian ini adalah $25 \%$ dari jumlah populasi sehingga penulis memperoleh sampel sebanyak 41 orang siswa yang diambil secara acak (random sampling) dan sampel yang diambil sesuai dengan kriteria. Tehnik pengumpulan data dalam penelitian ini observasi, wawancara dan angket. Data yang telah terkumpul dianalisis melalui tehnik perhitungan sederhana dengan menggunakan tabel frekuensi. Analisis data dilakukan dengan metode kuantitatif menggunakan rumus tabel frekuensi.

Kata Kunci: Peran Guru Pancasila dan Kewarganegaraan, Kenakalan Remaja

Abstract

This study aims to determine how the role of Civics teachers in preventing juvenile delinquency, as well as barriers experienced by teachers. The research method used by the author is quantitative descriptive. The population in this paper is all SMK students of 164 BAOs from class X, XI, XII. So the sample in this study is $25 \%$ of the total population so the authors obtained a sample of 41 students taken randomly and samples taken according to the criteria. Data collection techniques in this study were observations, interviews and questionnaires. The collected data is analyzed through simple calculation techniques using frequency tables. Data analysis is done by quantitative method using frequency table formula.
\end{abstract}

Keywords: The Role of Pancasila and Citizenship Teachers, Juvenile Delinquency

How to Cite: Wulandari, D.0 \& Hodriani (2019). Peran Guru Pendidikan Kewarganegaraan dalam Mencegah Kenakalan Remaja di Sekolah. Journal of Education, Humaniora and Social Sciences (JEHSS). 1 (3): 139-147.

\section{PENDAHULUAN}

Pada hakekatnya pendidikan adalah upaya sadar dari suatu masyarakat dan pemerintah untuk menjamin kelangsungan hidup dan kehidupan generasi penerus bangsanya. Selaku warga masyarakat, warga bangsa dan negara, tiap warga negara diharapkan berguna dan bermakna serta mampu mengantisipasi hari depan yang selalu mengalami perubahan sebagai dampak dinamika budaya dalam hubugan internasional. (Pasaribu, 2016).

Dalam sistem pendidikan nasional terselenggara dengan mengemban amanat untuk mencerdaskan kehidupan bangsa. Secara lebih rinci, amanat tersebut dijabarkan dalam UndangUndang Sistem Pendidikan Nasional Pasal 3 dan 4 yang berbunyi sebagai berikut: "Pendidikan Nasional berfungsi untuk mengemban kemampuan serta meningkatkan mutu kehidupan dan martabat manusia Indonesia dalam rangka upaya mewujudkan tujuan nasional (Pasal 3). Pendidikan nasional bertujuan mencerdaskan kehidupan bangsa yang mengembangkan manusia Indonesia seutuhnya, yaitu manusia yang beriman dan bertakwa terhadap Tuhan Yang Maha Esa 色

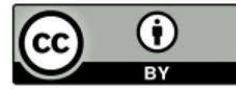


dan berbudi pekerti luhur, memiliki pengetahuan dan keterampilan kesehatan jasmani dan rohani, kepribadian yang mantap dan mandiri, serta tanggung jawab kemasyarakatan dan kebangsaan (Pasal 4)".

Apabila diperhatikan, pembelajaran Pendidikan Kewarganegaran untuk menyiapkan para siswa kelak sebagai warga masyarakat sekaligus sebagai warga negara yang baik (Tambunan, 2017). Sehubungan dengan tujuan pendidikan nasional tersebut, maka pembelajaran Pendidikan Kewarganegaraan pada jenjang pendidikan dasar dan menengah secara konseptual mengandung komitmen utama dalam pencapaian dimensi tujuan pengembangan kepribadian yang mantap dan mandiri serta tanggung jawab kemasyarakatan dan kebangsaan (Suharyanto, 2013).

Peran guru di sekolah dalam proses pendidikan, guru tidak hanya menjalankan fungsi alih dalam ilmu pengetahuan (transfer of knowledge), tetapi juga berfungsi untuk menanamkan nilai (value) serta membangun karakter (character building) peserta didik secara berkelanjutan dan berkesinambungan. Pendidik mempunyai tanggung jawab sebagai model yang harus memiliki nilai-nilai moral dan selalu memanfaatkan kesempatan untuk memengaruhi dan mengajak peserta didiknya. Selain itu, guru juga berperan sebagai pendidik (nurturer) yang berperan dan berkaitan dengan tugas-tugas memberi dorongan (supporter), tugas-tugas pembinaan (Supervisor) serta tugas-tugas yang berkaitan dengan mendisiplinkan anak agar anak itu menjadi patuh terhadap aturan-aturan sekolah dan norma hidup dalam keluarga dan masyarakat.

Dengan berkembangnya ilmu pengetahuan dan teknologi, banyak terjadi masalah dalam dunia pendidikan Indonesia. Salah satu masalah dalam dunia pendidikan Indonesia yang sedang menjadi sorotan publik saat ini yakni kasus kenakalan remaja dalam hal ini mereka sebagai siswa.

Masa remaja merupakan periode peralihan antara masa kanak-kanak dan dewasa. Pada masa ini remaja diantaranya mulai mencari identitas diri, sehingga seseorang yang sedang berada dalam masa remaja akan sangat mudah terpengaruh oleh hal di sekelilingnya, baik itu yang positif maupun yang negatif. Remaja yang positif adalah remaja yang memupuk sikap cinta lingkungan yang menghargai nilai-nilai kehidupan bangsa. Sedangkan, remaja yang negatif adalah remaja yang menimbulkan keresahan bagi lingkungan karena remaja yang melakukan tindakan nakal atau kriminal.

Menurut Jensen (dalam Sarwono, 2002) membagi kenakalan remaja menjadi empat aspek yaitu: 1) Kenakalan yang menimbulkan korban fisik pada orang lain: perkelahian, perkosaan, perampokan, pembunuhan, dan lain-lain; 2) Kenakalan yang menimbulkan korban materi: perusakan, pencurian, pencopetan, pemerasan, dan lain-lain; 3) Kenakalan sosial yang tidak menimbulkan korban di pihak orang lain: pelacuran, penyalahgunaan obat, dan hubungan seks bebas; 3) Kenakalan yang melawan status anak sebagai pelajar dengan cara membolos, kabur dari rumah, dan membantah perintah orang tua.

Kenakalan remaja yang diberitakan berbagai media massa dianggap makin meresahkan dan membahayakan masyarakat. Beberapa contoh ulah remaja belakangan ini makin mencemaskan masyarakat. Mereka tidak lagi sekedar terlibat dalam aktivitas nakal seperti membolos sekolah, merokok, minum-minuman keras, atau menggoda lawan jenisnya, tetapi tak jarang mereka terlibat dalam aksi tawuran layaknya preman, penjambretan, pemerasan, pencurian, perampokan, penganiayaan, perkelahian secara perorangan atau kelompok, mabukmabukan, penyalahgunaan obat-obatan seperti narkoba, terjerumus dalam kehidupan seksual pra-nikah, dan berbagai bentuk perilaku menyimpang lainnya.

Di kota-kota besar seperti Jakarta, Surabaya, Medan, dan Makasar tawuran sering terjadi. Komisi Nasional Perlindungan Anak (KPAI), mencatat sepanjang enam bulan pertama di tahun 2012, sudah ada 139 kasus tawuran pelajar. Naik dari tahun sebelumnya sebanyak 128 kasus. Tidak Cuma menyebabkan kerusakan saja, tetapi beberapa kasus diantaranya bahkan menyebabkan kematian. Jelas bahwa perkelahian pelajar ini merugikan banyak pihak (Dahniar, 2015). Di Kota Medan siswa SMA 3 dan SMA 4, tawuran di Adam Malik terjadinya aksi tawuran pelajar bermula dari perselisihan karena beberapa waktu yang lalu yang sempat saling ejek. Sejumlah pelajar terluka akibat terkena pukulan dan lemparan batu masalah ini terjadi pada awal 2017 dikabarkan merdeka.com. 
Melihat fenomena bentuk dan jenis kenakalan remaja tersebut, cenderung mengarah pada tindakan kriminal yang akhirnya berhadapan dengan aparat penegak hukum. Kenakalan remaja bukan hanya dilihat dari perbuatannya yang melawan hukum semata akan tetapi juga termasuk di dalamnya perbuatan yang menyimpang dari norma-norma masyarakat. Kenakalan remaja yang mengarah pada terganggunya keamanan, ketertiban dan ketenteraman masyarakat tentu akan meresahkan masyarakat. Padahal harapan bagi pemerintah, guru, dan orang tua terhadap generasi penerus harusnya sebagai warga masyarakat sekaligus sebagai warga negara yang baik.

Dalam hal ini cukup banyak yang melatar belakangi terjadinya kenakalan remaja. Berbagai faktor yang ada dapat dikelompokkan menjadi faktor internal dan eksternal. Adapun dalam faktor internal adanya perubahan biogis dan sosiologis pada remaja, dalam faktor eksternal kurangnya kasih sayang orang tua, terlebih lagi pada anak remaja yang berkecukupan materi dan biasa nya anak kurang perhatian dari orang tua maupun gurunya di sekolah. Masalah kenakalan anak sering menimbulkan kecemasan sosial karena obsesinya dapat menimbulkan kemungkinan gap generation sebab anak-anak yang diharapkan sebagai calon kader-kader penerus serta calon pemimpin bangsa banyak tergelincir dalam penyimpangan.

Berdasarkan hasil pengamatan di SMK Swasta PAB 6 Medan Estate menunjukkan bahwa masih terdapat siswa yang tidak disiplin atau nakal di sekolah, contohnya masih ada siswa yang melakukan pelanggaran terhadap tata tertib di sekolah. Pelanggaran yang dimaksud adalah bolos sekolah, merokok di lingkungan sekolah atau pun diluar sekolah dengan menggunakan seragam sekolah, dan berpakaian tidak rapi. Melihat dari situasi tempat sekolah SMK swasta PAB 6, sekolah yang satu yayasan PAB SMA 1 dan SMK 3 kenakalan-kenakalan yang berupa melanggar tata tertib di sekolah bisa menjadi dampak lebih besar yaitu adanya perkelahian yang membentuk suatu kelompok yang akan menjadi bentuk tawuran.

Dimana adanya perselihan antar sekolah yang berdekatan dan menimbulkankan suatu kesalapahaman seperti halnya pada saat-saat jam pelajaran kosong saat siswa menggunakan lapangan sekolah saling ingin bermain dari hal ini akan menimbulkan rasa egonya yang menyebabkan membentuk kelompok dan akan timbulnya perkelahian.

Masalah ini sebenarnya dapat diminimalisirkan oleh peran guru pendidikan kewarganegaraan dalam mencegah kenakalan remaja. Peran guru pendidikan kewarganegaraan berkaitan dengan tanggung jawab untuk membentuk perilaku siswa dalam kehidupan seharihari sebagai warga negara yang baik (Nasution, 2016). Strategi yang digunakan oleh guru dalam merancang sistem pembelajaran tersebut dengan menggunakan model, media dan kualitas pembelajaran yang efektif serta memberikan motivasi yang nantinya akan berpengaruh positif dalam pembentukan moral di sekolah (Khairat, 2016). Peserta didik dapat bersikap disiplin, berbudi luhur, berkarakter sesuai dengan budaya dan falsafah Pancasila (Setiawan, 2014).

\section{METODE PENELITIAN}

Penelitian Ferdinata, Peranan Guru Pendidikan Kewarganegraan Dalam Mengatasi Kenakan Siswa Di Sekolah (Studi Kasus di SMA Pasundan 7 Bandung). Hasil Penelitian: Rumusan masalah yang akan diteliti yaitu bagaimana peranan guru PKn dalam mengatasi kenakalan siswa di SMA Pasundan 7 Bandung. Tujuan penelitian ini sebagai pembuktian dari tujuan umum dan khusus yaitu untuk mengetahui bagaimana peranan guru PKn dalam upaya mengatasi kenakalan siswa di SMA Pasundan 7 Bandung melalui program pembelajaran secara terarah dengan berbagai aspek dalam nilai-nilai penghayatan sesuai dengan indikator kenakalan siswa untuk membentuk jati diri yang mempunyai sikap yang baik. Penulis menggunakan metode deskriptif yaitu penelitian yang memusatkan diri pada pemecahan masalah yang ada pada masa sekarang, yang aktual, dan data dikumpulkan, disusun, dijelaskan kemudian dianalisis, karena masalah yang diteliti sesuai dengan kriteria tersebut.

Hasil penelitian menunjukan bahwa dengan keyakinan dapat disimpulkan bahwa terdapat upaya dalam mengatasi kenakalan siswa yang cukup baik dalam peranan guru Pendidikan Kewarganegaraan (PKn) melalui pembelajaran secara terarah dengan berbagai aspek dalam nilai-nilai penghayatan sesuai dengan indikator mengatasi kenakalan siswa untuk membangun 
warga negara yang baik dan cerdas. Kesimpulan hasil penelitian yakni guru Pendidikan Kewarganegaraan (PKn) dapat melaksanakan program pembelajaran sesuai dengan peranannya sebagai guru Pendidikan Kewarganegaraan (PKn). Dapat melaksanakan program pembelajaran dengan langkah-langkah dalam mengatasi kenakalan siswa serta mampu mengatasi hambatan dan sudah berupaya membentuk karakter siswa agar menjadi warga negara yang baik dan cerdas dengan maksimal yaitu dengan tiada hentinya memberi nasehat dan sesekali memberi hukuman berupa sanksi kepada siswa yang tidak taat dan selalu memberi contoh perilaku yang mencerminkan kenakalan yang bertujuan pembentukan karakter kepada siswa agar menjadi warga negara yang baik.

Penelitian Suyatno, Peran Guru Pendidikan Kewarganegaraan dalam Mencegah Kenakalan Peserta Didik di SMP Negeri 1 Tanjungharjo Kabupaten Grobogan. Hasi Penelitian: Penelitian ini menggunakan pendekatan kualitatif. Lokasi penelitian yang dijadikan objek adalah SMP Negeri 1 Tanggungharjo Kecamatan Tanggungharjo Kabupaten Grobogan. Pengumpulan data dilakukan dengan menggunakan teknik wawancara, observasi, studi pustaka dan dokumentasi yang diolah dan diperiksa dengan menggunakan teknik trianggulasi untuk pengecekan keabsahan data. Teknik analisis data yang digunakan adalah analisis interaktif. Berdasarkan hasil penelitian dapat diambil simpulan bahwa (1) peran guru Pendidikan Kewarganegaraan (PKn) dalam mencegah kenakalan peserta didik di SMP Negeri 1 Tanggungharjo Kecamatan Tanggungharjo Kabupaten Grobogan, dilakukan melalui peran sebagai pembimbing, peran sebagai agen moral, peran sebagai model dan peran sebagai komunikator dalam kegiatan belajar mengajar sangat diperlukan, selain melaksanakan tugas mengajar, melatih, yang esensial adalah mendidik tingkahlaku, membina metal dan memberi bimbingan peserta didik agar tidak melanggar peraturan di sekolah dan untuk mengarahkan perkembangan psikologisnya.

Penelitian Felistya April Baetijanah, Peran Guru Pendidikan Kewarganegaraan (PKn) dalam Mencegah Kenakalan Remaja (Studi Deskriptif di SMK Negeri 3 Purwokerto). Hasil Penelitian guru diharapkan mampu berperan dalam mencegah kenakalan siswa, khususnya guru Pendidikan Kewarganegaraan (PKn) yang mengemban misi pembentukan warga negara yang baik. Tujuan umum yang ingin dicapai dalam penelitian ini adalah untuk mengetahui peran guru PKn dalam mencegah kenakalan remaja di SMK N. 3 Purwokerto. Pendekatan penelitian yang digunakan dalam penelitian ini adalah pendekatan kualitatif yang digunakan menggunakan metode studi deskeriptif analisis. Sumber data menggunakan data primer dan skunder. Subyek dalam penelitian ini adalah guru Pendidikan Kewarganegaraan (PKn), Waka Kesiswaan, Guru BK dan Perwakilan siswa SMK N. 3 Purwokerto. Tehnik pengumpulan data yang digunakan yaitu observasi, wawancara, dokumentasi, studi litelatur. Berdasarkan hasil penelitian yang dilakukan guru PKn mengkaitkan materi, media dan metode yang bervariasi untuk mencegah kenakalan yang dilakukan siswa. Diantaranya dengan menerapkan pembiasaan positif kepada siswa agar bisa juga diterapkan dalam kehidupan sehari-hari dirumah, selain itu guru juga selalu berusaha mengarahkan siswa supaya taat terhadap peraturan yang berlaku disekolah.

\section{HASIL DAN PEMBAHASAN} Kenakalan Remaja

Remaja dalam bahasa Inggris adalah adolescene, berasal dari bahasa latin adolescere yang berarti "tumbuh atau tumbuh untuk mencapai kematangan". Bangsa primitif dan orang-orang purbakala memandang masa puber dan masa remaja tidak berbeda dengan periode lain dalam kehidupan. Anak dianggap sudah dewasa apabila sudah mampu mengadakan reproduksi.

Piaget (Hurlock, 1991), yang mengatakan bahwa secara psikologis, remaja adalah suatu usia dimana individu menjadi terintegrasi kedalam masyarakat dewasa, di suatu usia dimana anak tidak merasa bahwa dirinya berada di bawah tingkat orang yang lebih tua melainkan merasa sama atau paling tidak sejajar. Remaja sebetulnya tidak mempunyai tempat yang jelas. Mereka sudah tidak tergolong anak-anak, tetapi belum juga dapat diterima secara penuh untuk masuk ke golongn orang dewasa. Remaja berada dia antara anak anak dan orang dewasa. Oleh karena itu remaja, seringkali dikenal dengan fase "mencari jati diri" atau fase "topan dan badai". 
Remaja masih belum mampu menguasai dan memfungsikan secara maksimal fungsi fisik maupun psikisnya.

Gunarsa (1986) mengemukakan "Remaja merupakan masa peralihan antara masa anak dan masa dewasa, yakni antara 12 sampai 21 tahun. Mengingat pengertian remaja, menunjukkan ke masa peralihan sampai tercapainya masa dewasa, maka sulit menentukan batas umurnya. Masa remaja mulai saat timbulnya perubahan-perubahan berkaitan dengan tanda-tanda kedewasaan fisik yakni umur 11 tahun atau mungkin 12 tahun pada wanita dan pada laki-laki lebih tua sedikit".

Pandangan lain dikemukakan oleh Daradjat (dalam Willis, 2005) sebagai berikut: "Remaja adalah usia transisi. Seseorang individu telah meninggalkan usia kanak-kanak yang lemah dan penuh ketergantungan, akan tetapi belum mampu ke usia yang kuat dan penuh tanggung jawab, baik terhadap dirinya maupun terhadap masyarakat, banyaknya masa transisi ini tergantung kepada keadaan dan tingkat social masyarakat dimana ia hidup. Semakin maju masyarakat semakin panjang usia remaja, karena ia harus mempersiapkan diri untuk menyesuaikan diri dalam masyarakat yang banyak syarat dan tuntutannya".

Jadi di dalam konsep diri memengang peranan penting dalam menentukan perilaku seseorang terutama bagi remaja. Dan dari konsep tersebut menjadi bagaimana seseorang memandang dirinya akan tercermin dalam keseluruhan perilakunya. Konsep diri juga mempunyai hubungan erat dengan prestasi belajar. Dimana disekolah anak yang mempunyai konsep diri yang baik biasanya akan memperoleh prestasi belajar yang baik dan sebaliknya.

Menurut Sudarsono (2004) kenakalan remaja (juvenile deliquency) "bukan hanya perbuatan atau pelanggaran yang dilakukan oleh anak remaja melawan hukum semata namun juga termasuk didalamnya perbuatan yang melanggar norma masyarakat, anti sosial, anti susila, dan menyalahi norma agama". Sehingga hal tersebut menimbulkan keresahan di lingkungan masyarakat, sekolah, dan keluarga.

Jadi kenakalan remaja adalah suatu bentuk yang terjadi karena remaja tersebut mengalami bentuk perubahan dalam diri dan melakukan tindakan yang melanggar norma dalam lingkungan dan perbuatan yang dilakukan meresah kan lingkungan.

Sunarwiyati S (1985) menurut bentuknya membagi kenakalan remaja kedalam tiga tingkatan (1) kenakalan biasa, seperti suka berkelahi, suka keluyuran, membolos sekolah, pergi dari rumah tanpa pamit (2) kenakalan yang menjurus pada pelanggaran dan kejahatan seperti mengendarai mobil tanpa SIM, mengambil barang orang tua tanpa izin (3) kenakalan khusus seperti penyalahgunaan narkotika, hubungan seks diluar nikah, pemerkosaan dll.

Menurut bentuknya kenakalan yang dilakukan remaja ada kenakalan yang tidak biasa yang hanya dapat merugikan dirinya akibat tindakan nya sendiri dan ada kenakalan yang tingkat nakalnya masuk kedalam tindakan kriminal, kenakalan seperti meresahkan masyarakat, orang tua dan sekolah.

\section{Peran Guru Pendidikan Kewarganegaraan}

Soekanto (1990) Peran adalah aspek dinamis dari kedudukan (status). Apabila seseorang melaksanakan hak dan kewajibannya sesuai dengan kedudukannya, maka dia menjalankan suatu peran. Linvinson juga turut memberikan pendapat (1990), 1) Peran meliputi norma-norma yang diungkapkan dengan posisi atau tempat seseorang dalam masyarakat. Peranan dalam arti merupakan rangkaian peraturan-peraturan yang membimbing seseorang dalam kehidupan masyarakata; 2) Peran adalah suatu konsep perihal apa yang dapat dilakukan oleh individu masyarakat sebagai individu; 3) Peran juga dapat dikatakan sebagai perilaku individu yang penting sebagai struktur sosial masyarakat.

Berdasarkan pendapat para ahli di atas bahwa peran merupakan suatu hal yang berhubungan dengan posisi atau kedudukan seseorang didalam lingkungan serta dalam hal ini sebagai orang yang memiliki hak dan kewajibannya sesuai dengan kedudukannya. Bahkan dia menjalankan perannya dapat lebih dari dimana tempat dia berada. 
Dasu Oka Wulandari \& Hodriana. Peran Guru Pendidikan Kewarganegaraan dalam Mencegah Kenakalan

Ali (1995) Peran merupakan perangkat perilaku yang diharapkan dimiliki oleh orang yang berkedudukan di masyarakat. Sehingga seseorang yang memiliki peran di masyarakat sangat diharapkan untuk dapat berperilaku dengan baik agar dapat memberikan contoh yang tauladan bagi anggota masyarakatnya sendiri. Putra (2001) dalam konteks proses reformasi menuju Indonesia baru dengan konsepsi masyarakat madani sebagai tatanan ideal sosial-kulturalnya, maka pendidikan kewarganegaraan mengemban misi: sosio-pedagogis, sosio-kultural, dan subtansi-akademis.

Menurut Nurman Somantri dalam Winarno (2013) mndefinisikan Pendidikan kewarganegaraan yang cocok dengan indonesia adalah sebagai program pendidikan yang berintikan demokrasi politik yang diperluas dengan sumber-sumber pengetahuan lainnya, pengaruh dari pendidikan sekolah, masyarakat dan orang tua yang kesemua itu diproses guna melatih para siswa untuk berpikir kritis, analitis, bersikap dan bertindak demokratis dan mempersiapkan hidup demokratis yang berdasarkan Pancasila UUD 1945.

Pendidikan Kewarganegaraan menurut Peraturan Menteri Pendidikan Nasional No. 22 Tahun 2006 tentang Standar isi untuk Satuan Pendidikan Dasar dan Menengah adalah mata pelajaran yang memfokuskan pada pembentukan warga negara yang memahami dan mampu melaksanakan hak-hak dan kewajibannya untuk menjadi warga negara Indonesia yang cerdas, terampil, dan berkarakter yang diamanatkan oleh Pancasila UUD 1945.

Berdasarkan ruang lingkup Pendidikan Kewarganegaraan (PKn) di atas, diketahui bahwa materi yang ada dalam Pendidikan Kewarganegaraan (PKn) diantaranya tentang materi nilainilai, norma dan peraturan hukum yang mengatur perilaku warga negara, sehingga diharapkan peserta didik dapat mengamalkan materi tersebut dalam kehidupan sehari-hari menjadi karakter pribadi yang melekata pada setiap individu peserta didik (Setiawan, 2014)

Jadi dalam lingkup Pendidikan Kewarganegaraan (PKn) tujuannya mengharapkan warga negara menjadi warga negara yang berkarakter dan bermoral. Guru adalah pendidik dan pengajar pada pendidikan anak usia dini jalur sekolah atau pendidikan formal, pendidikan dasar dan pendidikan menengah. Peran guru sebagai pendidik merupakan peran yang berkaitan dengan tugas memberi bantuan dan dorongan (support), tugas pengawasan dan pembinaan (supervisor) serta tugas yang berkaitan dengan mendisiplinkan peserta didik agar patuh terhadap aturan-aturan sekolah dan norma hidup dalam keluarga dan masyarakat.

Maka peran dan fungsi serta tanggung jawab guru Pendidikan Kewarganegaraan (PKn) sangat diharapkan mau dan mampu menjadikan para siswa sebagai calon warga masyarakat sekaligus sebagai warga negara yang baik. Tugas guru bukan hanya sekedar pada batas profesi yang meliputi mendidik, mengajar dan melatih saja. Akan tetapi guru juga bertugas dalam bidang kemanusiaan, yaitu guru disekolah harus dapat menempatkan dirinya sebagai orang tua kedua bagi siswanya dalam hal tingkah laku dan sikap disiplin terhadap peraturan yang berlaku baik dilingkungan sekolah maupun masyarakat.

Kaitannya dengan peran guru PKn, Soemantri (1976) berpendapat bahwa: Bahwa guru Pendidikan Kewarganegaraan (PKn) harus banyak berusaha agar siswa-siswanya mempunyai sikap yang baik, kecerdasan yang tinggi serta keterampilan yang bermanfaat. Oleh karena itu guru PKn harus dapat memanfaatkan fungsinya sebagai penuntun moral sikap serta memberi dorongan kearah yang baik.

Dapat disimpulkan menjadi seorang guru Pendidikan Kewarganegaraan (PKn) bukanlah sebagai peran yang biasanya yang hanya mentransfer ilmu tetapi memiliki tugas sebagai membentuk karakter siswa untuk menjadikan generasi yang berkualitas. Sehubungan dengan peran Pendidikan Kewarganegaraan (PKn) di atas, seorang guru PKn harus dapat mentransfer ilmu pengetahuan siswa agar siswa dapat memiliki potensi kepribadian yang baik sesuai dengan pelajaran PKn dalam menciptakan moral dan berpartisipasi untuk negara.

Maka guru Pendidikan Kewarganegaraan (PKn) memiliki tugas dan peran lebih dari guru mata pelajaran lain, hal ini berkaitan dengan tanggung jawab untuk membentuk perilaku siswa dalam kehidupan sehari-hari sebagai warga negara yang baik. Tugas guru Pendidikan Kewarganegaraan (PKn) bukan hanya mentransfer pengetahuan kepada siswa, tetapi juga mentransfer nilai-nilai yang diharapkan dapat dipahami, disadari, dan diwujudkan dalam 
perilaku baik siswa. Oleh karena itu, guru Pendidikan Kewarganegaraan (PKn) harus dapat memanfaatkan fungsinya sebagai penuntun moral, sikap serta memberi dorongan keras yang lebih baik.

Adapun pencegahan dalam kenakalan siswa yang dapat dilakukan oleh guru Pendidikan Kewarganegaraan. Menurut suhartini dan Simangusong (1989) adalah sebagai berikut: 1) Berusaha mengerti pribadi, Guru Pendidikan Kewarganegaraan berusaha untuk mengethui pribadi siswa, karena setiap siswa berbeda satu sama lainnya. Guru hendaknya Pendidikan Kewarganegaraan (PKn) dapat menemukan motif dan prinsip siswa dan berusaha untuk mendapatkan kepercayaan sehingga tercipta hubungan yang akrab dan terbuka. 2) Memberikan Perhatian yang serius, Perasaan guru Pendidikan Kewarganegaraan dilandasi dengan keseriusan dan kasih sayang dalam menghadapi keanekaragaman kepribadian dan cita-cita siswa. Agar siswa dapat menanamkan norma dan menjadi kepribadian siswa yang bermoral. 3) Menanamkan nilai-nilai Budi Pekerti kepada siswa melalui Pendidikan Agama, Melalui agama siswa dapat mengenal hak dan kewajiban, halal dan haram, ketakwaan dan ketawakalan lainnya sebagainya. Salah satu timbulnya kenakalan siswa adalah faktor keluarga oleh karena itu perlunya kerja sama guru Pendidikan Kewarganegaraan dan orang tua.

\section{SIMPULAN}

Guru Pendidikan Kewarganegaraan (PKn) memiliki tugas dan peran lebih dari guru mata pelajaran lain, hal ini berkaitan dengan tanggung jawab untuk membentuk perilaku siswa dalam kehidupan sehari-hari sebagai warga negara yang baik. Tugas guru Pendidikan Kewarganegaraan (PKn) bukan hanya mentransfer pengetahuan kepada siswa, tetapi juga mentransfer nilai-nilai yang diharapkan dapat dipahami, disadari, dan diwujudkan dalam perilaku baik siswa. Oleh karena itu, guru Pendidikan Kewarganegaraan (PKn) harus dapat memanfaatkan fungsinya sebagai penuntun moral, sikap serta memberi dorongan keras yang lebih baik. Kenakalan Remaja (Juvenile Deliquency) Perbuatan atau pelanggaran yang dilakukan oleh anak remaja melawan hukum semata namun juga termasuk didalamnya perbuatan yang melanggar norma masyarakat, anti sosial, anti susila, dan menyalahi norma agama". Sehingga hal tersebut menimbulkan keresahan di lingkungan masyarakat, sekolah, dan keluarga.

\section{DAFTAR PUSTAKA}

Akbar, P. (2008). Pengantar Statistik. Jakarta: Bumi Aksara

Amiruddin. (2013). Peranan Guru PKn Terhadap Pembentukan Moral Siswa SMP Negeri 10 Palu.

Aviyah, Evi. (2014). Religiusitas, Kontrol Diri dan Kenakalan Remaja. Jurnal Psikologi Indonesia. Vol 3. No. 2: Universitas Darul Ulum

Azizah. (2013). Kebahagian dan Permasalahan di Usia Remaja. JurnalBimbingan Konseling Islam. Vol 4. No. 2: Madrasah Ibtidiyah Tarbiatul Islam Kudus

Azzet, M.A. (2011). Urgensi Pendidikan Karakter di Indonesia. Jogjakarta: Ar-Ruzz Media

Fatimah, S dan Umuri, M.T. (2014). Faktor-faktor Penyebab Kenakalan Remaja di Desa Kemadang Kecamatan Tanjung Sari Kabupaten Gunung Kidul. Jurnal Citizenship. Vol. 4. No. 1: Universitas Ahmad Dahlan

Ferdinata. (2016). Peran Guru Pendidikan Kewarganegaraan Dalam Mengatasi Kenakalan Siswa di Sekolah (Studi Kasus di SMA Pasundan 7 Bandung. Jurusan Pendidikan Kewarganegaraan: Pasundan Bandung

Janah, F.A.B. (2013). Peran Guru Pendidikan Kewarganegaraan (PKn) Dalam Mencegah Kenakalan Remaja (Studi Deskriptif si SMK Negri 3 Purwokerto. Pendidikan Pancasila Dan Kewarganegaraan: Universitas Muhammadiyah Purwokerto.

Kartono, K. (2002). Patologi Sosial II: Kenakalan Remaja. Jakarta: Raja Grafindo

Khairat, (2016), Pembelajaran Contextual Teaching and Learning (CTL) dalam Meningkatkan Hasil Belajar Pendidikan Kewarganegaraan pada Materi Demokrasi, Jurnal Pendidikan Ilmu-Ilmu Sosial, 8 (1) (2016): 80-87.

Kurniawan, S dkk. Tawuran, Prasangka Terhadap Kelompok Siswa Lain, Serta Konformitas Pada Kelompok Teman Sebaya. Proyeksi, Vol. 4 No. 2: Universitas Islam Sultan Agung 
Dasu Oka Wulandari \& Hodriana. Peran Guru Pendidikan Kewarganegaraan dalam Mencegah Kenakalan

Kuswandi, F, Rina dan Chayono. S. (2015). Pengaruh Human Relation, Iklim Organisasi dan Etos Kerja terhadap Kinerja Pegawai Dinas Pendidikan Kota Banjar Baru. Jurnal Ilmiah Ekonomi Bisnis. Vol.1, No.8, Hal:10-18.

Lungan, R. (2010). Aplikasi Statistika dan Hitung Peluang. Yogyakarta: Graha Ilmu.

Mahmudi. (2009). Manajemen Kinerja Sektor Publik. Yogyakarta: UPP AMP YKPN.

Mangkunegara, A.P. (2011). Manajemen Sumber Daya Manusia Perusahaan. Bandung: PT. Remaja Rosdakarya.

Maunah, B. (2016). Sosiologi Pendidikan. Yogjakarta: Kali Media

Mulyasa, (2009). Menjadi Guru Profesional Menciptakan Pembelajaran yang Kreatif dan Menyenangkan. Bandung: Remaja Rosdakarya Offset

Munasef. (2008). Manajemen Kepegawaian Indonesia. Jakarta: PT. Gunung Agung.

Musfah, J. 2015. Menajemen Pendidikan. Jakarta: Kencana

Nasution, A.R., (2016), Urgensi Pendidikan Kewarganegaraan sebagai Pendidikan Karakter Bangsa Indonesia melalui Demokrasi, HAM dan Masyarakat Madani, Jurnal Pendidikan Ilmu-Ilmu Sosial, 8 (2) (2016): 201-212

Pasaribu, P. (2016). Pendidikan Kewarganegaraan. Medan: Unimed Press

Pinastika, F.D.P. (2016). Kebijakan Sekolah Dalam Mengatasi Kenakalan Siswa di SMK Perindustrian Yogyakarta. Jurnal Kebijakan Pendidikan Edisi 3. Vol V

Priyanto, A. (2012). Kriminologi. Yogjakarta: Ombak

Rambe, R. (2013). Kontribusi Pembelajaran PKn Dalam Upaya Pencegahan Terjadinya Kenakalan Remaja (Studi Kasus Siswa Kalas X SMK Nurhasanah Medan T.P 2010/ 2011). Jurnal Citizenship. Vol. 00. No. 00: Universitas Negeri Medan

Rifa'I, M. (2011). Sosiologi Pendidikan (Structur \& Interaksi Sosial Dalam Instusi Pendidikan. Jogjakarta: ArRuzz Media

Rivai, V, Basri, A.F.M. (2012). Performance Appraisal. Jakarta: PT. Raja Grafindo Persada.

Rukmana, W.E. (2010). Analisis Pengaruh Human Relation (Hubungan Antar Manusia) Dan Kondisi Fisik Lingkungan Terhadap Etos Kerja Dan Kinerja Karyawan Dedy Jaya Plaza Tegal. Skripsi. Universitas Dipenogoro. Semarang.

Sagala, S. (2013). Etika dan Moralitas Pendidikam. Jakarta: Kencana

Sandira. (2016). Persepsi Siswa SMAN 1 Payung Terhadap Kenakalan Remaja. Studia. Vol. 1. No. 1: Universitas STAIN

Sedarmayanti. (2009). Manajemen Sumber Daya Manusia, Reformasi Birokrasi dan Manajemen Pegawai Negeri Sipil. Bandung: PT. Refika Aditama.

Setiawan, D. (2014). Pendidikan Kewarganegaraan Berbasis Karakter melalui Penerapan Pendekatan Pembelajaran Aktif, Kreatif, Efektif dan Menyenangkan, Jurnal Pendidikan Ilmu-Ilmu Sosial, 6 (2): 6172

Setiawan, D. (2015). Kapita Selekta Kewarganegaraan. Medan: Larispa Indonesia

Siagian, S. P. (2012). Kiat Meningkatkan Produktivitas Kerja. Jakarta: PT Rineka Cipta.

Simamora, H. (2008). Manajemen Sumber Daya Manusia. Yogyakarta: STIE YKPN.

Simanjuntak, P.J. (2010). Manajemen dan Evaluasi Kinerja. Jakarta: FEUI

Sugiyono. (2014). Metode Penelitian Kuantitatif Kualitatif dan R\&D. Bandung: Alfabeta.

Suharyanto, A., (2013). Peranan Pendidikan Kewarganegaraan Dalam Membina Sikap Toleransi Antar Siswa, Jurnal Ilmu Pemerintahan dan Sosial Politik, 2 (1): 192-203

Sumara, D. (2017). Kenakalan Remaja dan Penangannya. Jurnal Penelitian \& PPM, Vol. 4. No. 2: Universitas Padjadjaran

Susanti, Eka Cahyana Putri, Al Musadieq Mochammad dan Ika Ruhanna. Pengaruh Human Relation (Hubungan Antar Manusia dan Kondisi Lingkungan Kerja terhadap Kinerja Karyawan. Jurnal Administrasi Bisnis. Vol.17, No.2, Hal:1-9

Suyatno. (2011). Peran Guru Pendidikan Kewarganegaraan Dalam Mencegah Kenakalan Peserta Didik Di SMP Negeri 1 Tanggungharjo Kecamatan Tanggungharjo Kabupaten Grobogan. Jurusan Hukum dan Hukum dan Kewarganegaraan: Universitas Negeri Semarang

Syarif, K. (2015). Perkembangan Peserta Didik. Medan: Unimed Press

Talumantak, Angreini, Kojo, Christoffel dan Lucky Dotulang. (2016). Analisis Pengaruh Human Relationship dan Beban Kerja terhadap Kinerja Pegawai pada Dinas Koperasi dan UMKM Provinsi Sulawesi Utara. Jurnal Berkala Ilmiah Efisiensi. Vol.16, No. 01, Hal:852-862

Tambunan, B., (2017). Upaya Meningkatkan Hasil Belajar Pendidikan Kewarganegaraan melalui Penerapan Model Pembelajaran Kooperatif Point-Counter-Point, Jurnal Pendidikan Ilmu-Ilmu Sosial, 9 (2): 239245

Umar, H, (2009). Manajemen Sumber Daya Manusia, Jakarta: Rineka Cipta. 
Wahyudi. (2013). Tinjauan Tentang Perilaku Konsumtif Remaja Pengunjung Mall Samarinda Central Plaza. eJournal Sosiologi. Vol. 1. No. 4: Universitas Mulawarman

Wibowo. (2012). Manajemen Kinerja. Jakarta: Rajawali Perss.

Winarno, (2014). Pembelajaran Pendidikan Kewarganegaraan. Jakarta: Bumi Aksara

Yulista, N.U. (2011). Upaya Sekolah Dalam Menanggulangi Kenakalan Siswa Di Sekolah Menengah Pertama Negeri 1 Panji Kabupaten Situbondo: Universitas Negeri Malang

Zuriah, N. (2008). Pendidikan Moral dan Budi Pekerti. Jakarta: Bumi Aksara 